of the same species? Two world wars have forced us to think of human beings and of farm animals as populations in a statistical sense. We count heads, assign 'man values' for energy requirements. Such a practice is essential for the administrator, but it does ignore individual differences. We have no evidence for variation in the efficiency of the fundamental biochemical processes with which individuals of the same species liberate energy from food. Yet human beings, as individuals, do differ in their instinctive demand for food. This difference is not necessarily correlated with the expenditure of energy. The obese human being within the nation is an inefficient individual. But the ox, fattening in his stall, is fulfilling his man-made destiny.

The assessment of the energy value of human and animal foods cannot then be studied as a problem in pure chemistry. In due time biochemistry will elucidate the complexities of the processes at molecular and cellular level which determine the liberation of energy from food. But the final word is with the living animal itself which is a biological entity. And a human being is also a person.

\title{
Methods of Assessing the Energy Values of Foods for Ruminant Animals
}

\author{
By K. L. Blaxter and N. McC. Graham, Hannah Dairy Research Institute, \\ Kirkhill, Ayr
}

The evaluation of animal feeding-stuffs has advanced in three major steps from the empirical and traditional knowledge contained in writings which, in this country, go back to the 16 th century. Immense progress was made when, in 1809 , Thaer introduced his system of evaluation based partly on chemical analyses of feedingstuffs carried out by Einhov and partly on the results of practical tests in which feeds were compared with a standard hay (Thaer, I809, I810, 1812, 1837, 1880). These 'hay values' were modified by Boussingault (1839), Liebig (1842), Grouven (1858) and others as information about the crude chemical composition of food accrued, and this knowledge led eventually to attempts to express requirements in terms of the protein, fat, carbohydrate and woody fibre the food contained (Wolff, I895). Thus the comparative aspect of 'Thaer's original system, containing as it did the elements of a biological assay, was lost and this approach did not again receive the attention it merited till the development of the food unit in Scandinavia by Winkel in 1880 , by Svendsen in 1896 and by Fjord in 1898 (see Eskedal, I954; Hansson, 1916).

With recognition of the fact that part of the feed energy is rejected by the animal in faeces and urine came the second advance in the introduction by Henneberg (1860) and by Wolff (1895) of the 'digestible nutrient' estimation which allowed for losses in the visible excreta. Their work led to assessment of the value of feeds in terms of total digestible nutrients, usually called T.D.N., (Atwater, I874-5, I890; Hills, I900; Hills, Jones \& Benedict, I910; Woll \& Humphrey, I910) and 
indeed it led also to the fuel values used in human nutrition (Atwater \& Bryant, 1900; Rubner, I885).

The third stage consisted in the formulation of the net-energy concept by Kühn and Kellner (Kellner, I905, I912, I920; Kellner \& Kohler, I900) working at Möckern (Leipzig, Germany) and Armsby (1905, I909, I917) working at State College, Pennsylvania (U.S.A.) about 50 years ago. In this principle is sought a thermodynamically sound measure of that part of the energy of food actually available to the animal for maintaining its vital processes, for muscular work and for productive purposes. The best estimate of feed value is then the calorific value of the protein and fat deposited in the body or which may be contained in the eggs or milk produced when a unit of the feed is eaten. Thus, not only is the gross energy of the feed taxed for the inevitable losses of energy in faeces, urine and as combustible gas, but also for the heat associated with its ingestion, digestion and metabolism. The net calorie of Armsby and the starch value of Kellner are equivalent measurements ( $1 \mathrm{~kg} \mathrm{S.E.}=2360$ net Cal. for fattening), and express the value of the feed in terms of the final response it promotes, namely energy retention and production of eggs or milk (Armsby \& Fries, 1919).

It is important to emphasize that an energy value is a biological measure. The efficiency with which an animal utilizes the gross energy of a food provides the measure of its nutritive value. Consequently, variation in the digestive and metabolic patterns of the animal must necessarily be reflected in concomitant variation in the estimated value of the food it consumes. Many who compute rations and diets lose sight of this fact and regard nutritive values as physical constants rather than statistical averages of physiological responses. Unfortunately, factual information is so meagre that tabulated feed values do not merit even this latter appellation.

Energy values of feeds are needed by those who plan rations for individual animals or herds, by those who plan cropping programmes for farms or even countries and by those who import feeds to supplement those grown at home. Thus any system of evaluation must place feeds in correct order on a quantitative scale in terms of their ability to maintain the production of livestock. Some indication of variability is also desirable and if, from attributes of the sample-its chemical composition for example, or, with complex mixtures like hay or silage, botanical make-up and subsequent processing-it is possible to predict more closely the range in which its energy value is liable to fall, so much the better.

The terminology usually adopted in energy studies is as follows:

Gross energy $=$ heat of combustion,

Digestible energy $=$ gross energy of feed less gross energy of faeces,

Metabolizable energy = digestible energy less the gross energy of urine and combustible gases resulting from fermentation in the gut,

Heat increment $=$ the increase of heat production corresponding to an increase of food intake,

Net energy $=$ metabolizable energy less the heat increment. 
In Table $\mathrm{I}$ from our unpublished work, a high-quality dried grass is compared with one of low quality on the basis of each of the energy categories mentioned above. It will be noticed that whereas their gross energies are very close, their digestible and metabolizable energies differ considerably. Their net energies are even more widely different because of the greater heat increment per metabolizable Cal. associated with ingestion of the coarser grass. This change does not arise from the protein metabolism, a peculiarity of ruminant nutrition being the high increment of heat associated with the ingestion of fibrous carbohydrates.

Table I. Energy categories (Cal./100 g dry matter of feed) for high and low qualities of dried grass at the same level of intake determined by experiments on sheep (Blaxter $\mathscr{O}^{\circ}$ Graham, 1954, unpublished)

Energy category

Gross energy of feed Digestible energy Metabolizable energy Net energy
Grass A*

(I)

484

369

321

$2 \times 9$
Grass B†

(2)

433

214

166

93
(I) as a percentage of (2)

112
172
193
235

* High-quality dried grass: $25.8 \%$ crude fibre, $19.7 \%$ crude protein.

† Low-quality dried grass: $32 \cdot 3 \%$ crude fibre, $8.6 \%$ crude protein.

Many experimental results are available that support these findings. Thus, Nordfeldt, Iwanaga, Morita, Henke \& Tom (1950) found that when cows were fed constant amounts of T.D.N., increasing the proportion of fibre (hay) reduced the milk yield. Similar results had been obtained with fattening oxen 40 years previously (Schneiderwind, 1910). Yates, Boyd \& Pettit (1942) showed the same effect to have occurred in Danish feeding trials, and in experiments with horses Olsson (195 I) found that replacing concentrates with hay on the basis of metabolizable energy resulted in a loss of body-weight, whereas weight was maintained when net energy was the criterion. Again, in recent work of Huffman (Huffman, Duncan \& Chance, I952) purporting to demonstrate the presence of specific lactationpromoting factors in grain, T.D.N. was the basis on which grain was replaced by hay. However, the magnitude of the effect was such that it would not have appeared if the net-energy system had been used in the calculation. This has also been the conclusion of Irwin, Shaw, Saarinen \& Moore (195I).

Mitchell has suggested that the efficiency of utilization of metabolizable energy might be constant for all balanced rations (Mitchell, 1934, 1937; Mitchell, Hamilton \& Haines, 194I). However, an imbalance between energy and protein cannot account for the differences found in the calorimetric experiments and the feeding trials quoted above. Gross or subclinical mineral or vitamin deficiencies might do so (Kleiber, 1945-6) though this is not necessarily so (Blaxter \& Rook, I955). If structural and other carbohydrates are considered with regard to balance, then the hypothesis may well be tenable though it would still not support the use of metabolizable-energy values for comparative purposes since rations differ greatly in their content of fibrous constituents. The same remarks apply to Forbes's concept of maximal normal nutritive value (Forbes, I933). 
On the same basis Axelsson's (1939, 1945) argument that there is an optimum fibre content for maximal utilization of metabolizable energy in a ration, even if it is true, which is unlikely (Breirem, 1944, 1953), does not lend support to the use of metabolizable energy for feed evaluation. The practical success of 'forage farming' (depending on roughage feeds) on the one hand and the 'Boutflour system' (using mainly concentrate feeds) on the other, makes it quite clear that the existence of any physiological fibre optimum has little economic significance.

Thus, net energy, on which the starch-equivalent system used in this country for the past 30-40 years depends (see Woodman, r948), is seen to provide a superior measure of feed value to that provided by either digestible or metabolizable calories.

Since net energy takes account of the heat increment of feeding, it is a differential quantity and may be more clearly described as the increase in energy retention per unit increase in food consumption. Its determination with ruminants necessitates measurement of the heating effect of a food during at least $24 \mathrm{~h}$, the animal having attained a fixed metabolic pattern as a result of subjection to a steady feeding régime for the previous $\mathrm{r}^{-2 \mathrm{I}}$ days. This type of experimentation must be used because of the long time course of ruminant digestion (Balch, 1950; Blaxter, Graham \& Wainman, 1955). Thus, in sheep microbial dissimilation can still be detected after $80 \mathrm{~h}$ of fast (Blaxter \& Graham, 1955). In fact, steady-state measurements are necessary in work with any non-cooperative species, in contrast with the investigation of human metabolism where the effect of a single meal may be followed over several hours, though even here, too short a time is often used (Glickman, Mitchell, Lambert \& Keeton, r948).

The practical problem of measuring energy retention has exercised the ingenuity of most workers in this field. The classical method which originated in the Pettenkofer-Voit-Rubner school (see Rubner, 1903) consists of simultaneous determination of the carbon and nitrogen retention from which, knowing the carbon content of the fat and the carbon and nitrogen content of the protein deposited in the body, together with the calorific values of this fat and protein, the energy storage may be computed (see Blaxter \& Rook, I953).

A second method which depends on calculation of the heat production from the non-protein respiratory quotient and the oxygen consumption (or $\mathrm{CO}_{2}$ production) is based on the original researches of Regnault \& Reiset (1849) into the significance of the respiratory quotient, on the calorific value of oxygen (Zuntz \& Schumburg, Igor; Benedict \& 'Talbot, 19I4), and on the truth of Hess's law of constant heat summation (see Glasstone, 1948).

In the third method, heat output is measured by means of a suitably sized animal calorimeter (Armsby, 1904; Hagemann, I9II; Tangl, 1912; Capstick, 1921). However, following the work of Armsby (1913), Benedict \& Lee (1937) and others in the field of human and non-ruminant nutrition (e.g. Rubner, 1894; Atwater \& Rosa, I 897), direct determination of heat loss is now regarded as unnecessarily exacting for the purpose concerned.

Some of the apparatus built by the earlier workers, excellent accounts of which are given by Tigerstedt (I9II), Lusk (1928) and Paechtner (I93I), to-day appear 
fantastically complicated though the instrumental accuracy of the various respiration chambers and calorimeters was within $\pm 1 \%$ of the measured heat production.

The classical method of determining a net-energy value is the difference experiment (see Møllgaard, I929) in which the test feed is added to a basal ration and the increment in energy retention obtained by difference. Corrections have been applied to the crude figures from time to time, e.g. correction for activity variation (Armsby \& Fries, r913), for departure from nitrogen equilibrium (Armsby, 1917, p. 640) and for the energy cost of maintaining the increased body-weight at the higher nutritional level (Swift, 1942), though the logic behind most of them is difficult to follow.

The major problem that arises in these experiments concerns the level of energy retention at which they are carried out, because the net energy falls off as the feed intake rises (Forbes, Braman \& Kriss, I928, 1930; Weigner \& Ghoneim, I930; Forbes, Kriss \& Miller, 1934; Mitchell et al. 1932; Hellberg, 1949; Blaxter \& Graham, 1955). Whereas much of Armsby's work was done with a food intake causing loss of body energy, both Kellner and Fingerling used supermaintenance rations. Forbes has suggested that the decrease of net energy with increasing food intake ceases to be significant once the point of energy equilibrium has been passed, but none of the experiments referred to above seem to support this contention, even Marston's (I948) results on recalculation contradict the suggestion (see also Hellberg, 1949). This curvilinear relationship accounts for the apparently greater efficiency of food utilization for maintenance compared with that for production. The concept of a minimum base-value of heat production is in fact an attempt to express a smooth curvilinear function as two straight lines (Forbes \& Swift, r 94I).

These findings mean that net-energy values determined by the earlier workers have a mixed significance and some care is needed in their practical application. For any value to be of use it would seem essential to know at what plane of nutrition it was determined and how its magnitude varies with feed intake. In addition, modification of existing tables of feed values seems desirable to make the usual additive system of computing rations legitimate.

The extent of between-animal variation in estimates of net energy is shown in Table 2 which sets out some of Kellner's and Fingerling's results. From comparable data Kleiber (1929) calculated that the coefficient of variation is about I $\%$. Part of this high variability may be due not to differences between individuals but to the method of measurement. Thus in our experiments, the error attached to an estimate of energy retention in a 4 -day respiration trial is about $\pm 1 \%$ of the energy intake, all analytical work being within limits of $\pm 0.5 \%$. Since a net-energy value is a difference between two energy balances divided by the weight of the increment of food, the error of an individual estimation increases as the size of the food increment falls. In the Möckern experiments (see p. 132) it was usual to add about $2 \mathrm{~kg}$ of the trial feed to $6-8 \mathrm{~kg}$ of basal ration. So, if errors of the same magnitude as we find had applied, each net-energy determination would vary by $\pm 20-30 \mathrm{Cal}$./ 
Table 2. Estimations of net energy in experiments of Kellner $\mathscr{F}^{\circ}$ Fingerling from the summary of work at Möckern showing extent of variation (Werner $\mathscr{O}^{\circ}$ Franke, 1954)

\begin{tabular}{|c|c|c|}
\hline Feed & $\begin{array}{c}\text { Starch } \\
\text { equivalent }\end{array}$ & $\begin{array}{l}\text { Individual estimates of } \\
\text { net Cal./100 g digested } \\
\text { organic matter }\end{array}$ \\
\hline Swedes & $\begin{array}{l}52 \cdot 1 \\
52 \cdot 5 \\
48 \cdot 9\end{array}$ & $\begin{array}{l}157 \cdot 6 \\
156 \cdot 4 \\
147 \cdot 1\end{array}$ \\
\hline Rye bran & $\begin{array}{l}46 \cdot 0 \\
59 \cdot 9 \\
4 \mathrm{I} \cdot 2\end{array}$ & $\begin{array}{l}171 \cdot 9 \\
220 \cdot 0 \\
157 \cdot 2\end{array}$ \\
\hline Rice meal & $\begin{array}{l}67 \cdot 0 \\
81.1\end{array}$ & $\begin{array}{l}331 \cdot 4 \\
316 \cdot 0\end{array}$ \\
\hline Wheat straw & $\begin{array}{l}15.3 \\
17.0\end{array}$ & $\begin{array}{l}83 \cdot 6 \\
95 \cdot 5\end{array}$ \\
\hline $\begin{array}{l}\text { 'Pure nutrients': } \\
\text { Potato starch } \\
\text { Gluten flour } \\
\text { Arachis oil } \\
\text { Straw fibre }\end{array}$ & $\begin{array}{l}\bar{z} \\
\overline{-}\end{array}$ & $\begin{array}{l}I 72 \cdot 1-251 \cdot 5 \\
162 \cdot 4-227 \cdot 3 \\
37 I \cdot 8-439 \cdot 3 \\
191 \cdot 4-215 \cdot 0\end{array}$ \\
\hline
\end{tabular}

Ioog dry matter or $\pm 0 \cdot 8-\mathrm{I} \cdot 3$ units of starch equivalent. It would appear therefore that part of the variation may quite easily have arisen as a result of small technical and analytical errors.

Within-species, between-animal variation undoubtedly exists, but at present there is little information available other than that in some early work of Armsby (1917, pp. 285, 304, 442) and of Wood \& Hill (1914) to indicate its magnitude, though we are at present accumulating data relevant to this issue. A range of $15 \%$ appears likely (Blaxter \& Wood, r952).

A further point concerns the possible effect of the basal ration on the test feed. In Table 3 some results of Forbes (Forbes, Braman, Kriss \& Swift, I 933) are summarized (see Kriss, I943). These show variations in the energy values of maize and lucerne hay which cannot be attributed to differences in plane of nutrition. The difference method thus appears to involve an invalid assumption of the independent action of feeds. Such associative effects are also present when feed value is assessed on the basis of gross or of metabolizable energy.

A more recent development in this field has been the attempt by Kleiber, (Kleiber, Regan \& Mead, I945) to combine the comparative method of Fjord and the calorimetric method in a 'replacement value' using a glucose-casein mixture as a standard. Kleiber tends to the opinion, as we do, that comparative feeding trials can give reliable measures of energy value. This view also has the support of Fraps (1937) and Morrison (1937) and is the basis of the American production coefficients employed in poultry nutrition.

Despite the limitations that have been associated with their estimation, net- 
Table 3. Estimates of net energy and net availability of metabolizable energy of maize and Lucerne hay*

$\begin{array}{lcc}\text { Ration } & \begin{array}{c}\text { Net energy } \\ \text { (Cal./kg) }\end{array} & \begin{array}{c}\text { Net availability of } \\ \text { metabolizable } \\ \text { energy }(\%)\end{array} \\ \text { nne hay }+ \text { maize } & 4416 & 84 \\ \text { ne hay } & 1293 & 68 \\ \text { by difference }(\mathrm{I}-2) & 3123 & 94 \\ \text { alone } & 2805 & 84 \\ \text { by difference }(\mathrm{I}-4) & 161 \mathrm{I} & 85\end{array}$

(I) Lucerne hay + maize

(2) Lucerne hay

(3) Maize by difference $(\mathrm{I}-2)$

(4) Maize alone

(5) Hay by difference $(\mathrm{I}-4)$

1611

* From the experiments of Forbes et al. (1933) summarized by Kriss (1943).

energy values in one form or another-starch equivalents, fodder units, net calories for fattening, Kellner values (Fuchs, 1954)-are in widespread use. In the Ministry of Agriculture \& Fisheries Bulletin no. I24 (Woodman, 1942) starch equivalents are listed for 286 feeding-stuffs. In the 60 years of work at Möckern, only seventyfive experiments on fifty-one samples of thirty-seven feeds were carried out, the majority of them between 1890 and 1905 (see summary by Werner \& Franke, 1953), that is before the enormous growth of the food-processing industry, before the advent of artificial dehydration procedures and before the impetus to improved varieties of crop plants had reached its present peak. Most of the figures given in tables of starch equivalents have been computed from digested nutrients using the values which Kellner proposed for the net energy of digestible 'pure' nutrients, and contain the corrections which Kellner had to apply to remove the discrepancy between the calculated and directly determined starch equivalents of coarse and concentrated feeds (Kellner, I9I2). Using modern statistical techniques Breirem (1944, 1954) has investigated this discrepancy and found very considerable residual variability to be present. The accuracy of prediction, assuming Kellner's original limited work to be of absolute precision, is in the region of \pm 6 units of starch equivalent. Modifications of the factors, the use of 'true' rather than crude protein, application of different corrections for chaffed or milled feeds (Woodman, 1948, p. I2) and the dependence of the discrepancy on 'ballast' or fill have all been considered in attempts to increase the accuracy of prediction. The suggestion by Lehmann (194I) that the discrepancy was dependent on fill was based on an analysis of experiments with nine roughages made by Kellner and the correction depends on the use of indigestible organic matter to correct for the fibre effect and may be compared with Armsby's method of computing energy values in which he regards heat losses as relatively constant per kg dry matter ingested, differences in nutritive value being mainly due to variation in metabolizable energy per kg food (Armsby, 1917, p. 673).

In the period since Kühn and Kellner, the consolidation and extension of the net-energy principle, which might have been expected to have occurred as a result of such brilliant work, has, with several notable exceptions, not taken place. Instead, the period has been characterized by polemical argument rarely illumined by an experiment and hardly ever by a calorimetric trial. Kellner's original work has been 
recalculated, re-expressed and, in short, sucked dry. Thus instead of expressing food values in terms of the net-energy calories per $\mathrm{kg}$ food, the value has been expressed inversely as the weight of food that contains roo० Cal. New food units in which the number of net calories per food unit has been redefined, are scattered thickly through the literature. Nothing new has been contributed in any of these arithmetical processes. Clearly, in the assessment of the nutritive value of foods, the future must involve extensive experimentation and measurement rather than the almost complete dependence on pioneer evidence which has characterized the past 50 years.

\section{REFERENCES}

Armsby, H. P. (1904). Exp. Sta. Rec. 15, 1037.

Armsby, H. P. (1905). Bull. Pa agric. Exp. Sta. no. 7r.

Armsby, H. P. (1909). Fmrs' Bull. U.S. Dep. Agric. no. 346.

Armsby, H. P. (1913). F. Amer. chem. Soc. 35, I794.

Armsby, H. P. (1917). The Nutrition of Farm Animals. New York: The Macmillan Co.

Armsby, H. P. \& Fries, J. A. (1913). Amer. F. Physiol. 3I, 245.

Armsby, H. P. \& Fries, J. A. (1919). F. agric. Sci. 9, 182.

Atwater, W. O. (1874-5). Rep. Conn. Bd agric. 8, 13 I.

Atwater, W. O. (189o). Rep. Storrs agric. Exp. Sta. p. I74.

Atwater, W. O. \& Bryant, A. P. (I900). Rep. Storrs agric. Exp. Sta. I899, p. 73.

Atwater, W. O. \& Rosa, E. B. (1897). Bull. U.S. Off. Exp. Stas, no. 44.

Axelsson, J. (1939). Tierernährung, Ir, I76.

Axelsson, J. (I945). K. Landtbr Akad. Handl., Stockh., 84, 259.

Balch, C. C. (1950). Brit. F. Nutr. 4, 36r.

Benedict, F. G. \& Lee, R. C. (1937). Publ. Carneg. Instn, no. 489.

Benedict, F. G. \& Talbot, F. B. (1914). Publ. Carneg. Instn, no. 201.

Blaxter, K. L. \& Graham, N. McC. (1955). F. agric. Sci. (In the Press.)

Blaxter, K. L., Graham, N. McC. \& Wainman, F. W. (1955). Proc. Nutr. Soc. 14, iv.

Blaxter, K. L. \& Rook, J. A. F. (1953). Brit. F. Nutr. 7, $8_{3}$.

Blaxter, K. L. \& Rook, J. A. F. (1955), Brit. F. Nutr. 9, 121.

Blaxter, K. L. \& Wood, W. A. (1952). Brit. F. Nutr. 6, I.

Boussingault, J. B. (1839). Ann. Chim. (Phys.) Ser. 2, 71, I 13.

Breirem, K. (1944). K. LandtbrAkad. Handl., Stockh., 83, 345.

Breirem, K. (1953). Tidsskr. norske Landbr. 60, 25.

Breirem, K. (1954). In Festschrift anlässlich des Ioojährigen Bestehens der Landwirtschaftlichen Versuchsstation Leipzig-Möckern. Vol. 2. 100 Fahre Möckern. Die Bewertung der Futterstoffe und andere Probleme der Tierernährung, p. 91. [K. Nehring, editor.] Berlin: Deutscher Bauernverlag.

Capstick, J. W. (1921). F. agric. Sci. 11, 408.

Eskedal, W. (1954). In Festschrift annlässlich des 1oojährigen Bestehens der Landwirtschaftlichen Versuchsstation Leipzig-Möckern. Vol. 2. roo Fahre Möckern. Die Bewertung der Futterstoffe und andere Probleme der Tierernährung, p. 2 19. [K. Nehring, editor.] Berlin: Deutscher Bauernverlag.

Forbes, E. B. (1933). Science, 77, 306 .

Forbes, E. B., Braman, W. W. \& Kriss, M. (1928). F. agric. Res. 37, 253.

Forbes, E. B., Braman, W. W. \& Kriss, M. (1930). J. agric. Res. 40, 37.

Forbes, E. B., Braman, W. W., Kriss, M. \& Swift, R. W. (1933). F. agric. Res. 46, 753.

Forbes, E. B., Kriss, M. \& Miller, R. C. (1934). F. Nutr. 8, 535 .

Forbes, E. B. \& Swift, R. W. (194I). Bull. Pa agric. Exp. Sta. no. 415.

Fraps, G. S. (1937). Proc. Amer. Soc. Anim. Prod. p. 20.

Fuchs, P. (1954). In Festschrift anlässlich des roojährigen Bestehens der Landwirtschaftlichen Versuchs. station Leipzig-Möckern. Vol. 2. roo Fahre Möckern. Die Bewertung der Futterstoffe und andere Probleme der Tierernährung, p. 165. [K. Nehring, editor.] Berlin: Deutscher Bauernverlag.

Glasstone, S. (1948). Textbook of Physical Chemistry, and ed. London: Macmillan and Co.

Glickman, N., Mitchell, H. H., Lambert, E. H. \& Keeton, R. W. (1948). F. Nutr. 36, 41.

Grouven, H. (1858). Vörtrage über Agrikulturchemie.

Hagemann, O. (I91 1). Landw. Fb. 41, supplementary vol. I, I.

Hansson, N. (1916). Handbok I Utfodringslära. Stockholm: C. E. Fritzes Bokförlags Aktiebolag.

Hellberg, A. (1949). Metabolism of Rabbits at Different Planes of Nutrition. Uppsala: Almquist \& Wiksells Boktryckeri. 
Henneberg, W. (1860). Beitrage zur Begrïndung einer rationellen Fütterung der Wiederkäuer, Vol. I. Brunswick: Schwetschke u. Sohn.

Hills, J. L. (1900). Bull. Vt agric. Exp. Sta. no. 8I.

Hills, J. L., Jones, C. H. \& Benedict, P. A. (1910). Bull. Vt agric. Exp. Sta. no. I 52.

Huffman, C. F., Duncan, C. W. \& Chance, C. M. (1952). F. Dairy Sci. 35, 4I.

Irwin, H. M., Shaw, J. C., Saarinen, P. \& Moore, L. A. (1951). F. Anim. Sci. 10, 947.

Kellner, O. (1905). Die Ernährung der Landwirtschaftlichen Nutztiere, ist ed. Berlin: Parey.

Kellner, O. (1912). Die Ernährung der Landwirtschaftlichen Nutztiere, 6th ed. Berlin: Parey.

Kellner, O. (1920). Die Ernährung der Landwirtschaftlichen Nutztiere, gth ed. Berlin: Parey.

Kellner, O. \& Köhler, A. (I900). Landw. Versuchsw. 53, I.

Kleiber, M. (1929). Fortschr. Landw. 4, 33.

Kleiber, M. (1945-6). Nutr. Abstr. Rev. r5, 207.

Kleiber, M., Regan, W. M. \& Mead, S. W. (r945). Hilgardia, r6, 5 I r.

Kriss, M. (1943). F. Anim. Sci. 2, 63 .

Lehmann, F. (1941). Z. Tierernähr. 5, 155 .

Liebig, J. (1842). Chimie Organique appliquée à la Physiologie des Animaux.

Lusk, G. (1928). The Elements of the Science of Nutrition, $4^{\text {th }}$ ed. Philadelphia and London: W. B. Saunders Co.

Marston, H, R. (1948). Aust. 7. sci. Res., Ser. B, r, 93.

Mitchell, H. H. (1934). Science, 80, $55^{8}$.

Mitchell, H. H. (1937). Proc. Amer. Soc. Anim. Prod. p. 29.

Mitchell, H. H., Hamilton, T. S. \& Haines, W. T. (1932). F. agric. Res. $45,163$.

Mitchell, H. H., Hamilton, T. S. \& Haines, W. T. (194r). F. Nutr. 22, 54I.

Mollgaard, H. (1929). Fütterungslehre des Milchviehs. Hannover: M. \& H. Schaper.

Morrison, F. B. (1937). Proc. Amer. Soc. Anim. Prod. p. I2.

Nordfeldt, S., Iwanaga, I., Morita, K., Henke, L. A. \& Tom, A. K. S. (I950). F. Dairy Sci. 33, 473

Olsson, N. (1951). Medd. LantbrHögsk. Husdjurs Förs Anst. no. 47.

Paechtner, J. (1931). Der Gaswechsel. In Mangold's Handbuch der Ernährung und des Stoffwechsels der Landw. Nutztiere, 3, 365. Berlin: Julius Springer.

Regnault, V. \& Reiset, J. (1849). Ann. Chim. (Phys.) 26, 299.

Rubner, M. (1885). Z. Biol. 21, 250.

Rubner, M. (1894). Z. Biol. 30, 73 .

Rubner, M. (1903). Die Gesetze des Energieverbrauchs bei der Ernährung. Leipzig u. Wien: F. Deuticke.

Schneiderwind, W. (1910). Dtsch. landw. Pr. 37, 1123.

Swift, R. W. (1942). F. Anim. Sci. 1, 145.

Tangl, F. (1912). Biochem. Z. 44, 235.

Thaer, A. (1809). Grundsatz der Rationellen Landwirtschaft, ist ed. Berlin: Parey.

Thaer, A. (1810). Grundsatz der Rationellen Landwirtschaft, and ed. Berlin: Parey.

Thaer, A. (1812). Grundsatz der Rationellen Landwirtschaft, 3rd ed. Berlin: Parey.

Thaer, A. (1837). Grundsatz der Rationellen Landwirtschaft, 4th ed. Berlin: Parey.

Thaer, A. (1880). Grundsatz der Rationellen Landwirtschaft, new ed. Berlin: Parey.

Tigerstedt, R. (I91 I). Hanb. Physiol. Meth. I, Sect. 3, p. 7I.

Weigner, G. \& Ghoneim, A. (1930). Tierernährung, 2, I93.

Werner, A. \& Franke, E. R. (1953). In Festschrift anlässlich des roojährigen Bestehens der Landwirtschaftlichen Versuchsstation Leipzig-Möckern. Vol. I. Untersuchungen über den Stärkewert verschiedener Futtermittel, p. 335. [K. Nehring and A. Werner, editors.] Berlin: Deutscher Bauernverlag.

Wolff, E. (1895). Farm Foods. (English translation by H. H. Cousins of Landwirtschaftliche Fütterungslehre, 6th ed.) London: Gurney and Jackson.

Woll, F. W. \& Humphrey, G. C. (1910). Res. Bull. Wis. agric. Exp. Sta. no. 13.

Wood, T. B. \& Hill, A. V. (19r4). F. agric. Sci. 6, 252.

Woodman, H. E. (1942). Bull. Minist. Agric., Lond., no. 124.

Woodman, H. E. (1948). Bull. Minist. Agric., Lond., no. 48, inth ed.

Yates, F., Boyd, D. A. \& Pettit, G. H. N. (1942). F. agric. Sci. 32, 428.

Zuntz, N. \& Schumburg, (I90I). Studien zu einer Physiologie des Marsches. Berlin: Hirschwald. 